Jurnal DIALOGIKA Manajemen dan Administrasi

Homepage: https://ejournal.unma.ac.id/index.php/dialogika

Vol. 1 No. 2 April 2020, halaman: $76 \sim 85$

E-ISSN: 2720-9865, P-ISSN: 2716-3563

DOI : https://doi.org/10.31949/dialogika.v1i2.2171

\title{
PENGARUH IKLIM ORGANISASI DAN PENGEMBANGAN KARIR TERHADAP KEPUASAN KERJA SERTA DAMPAKNYA PADA KUALITAS PELAYANAN
}

\author{
Endang Hermawan \\ Alumni Pascasarjana, Universitas Majalengka, Jawa Barat, Indonesia \\ e-mail korespondensi: endanghermawan@gmail.com
}

Disubmit Februari 2020 , Diterima Maret 2020 , Diterbitkan April 2020

Submitted February 2020, Accepted March 2020, Published April 2020

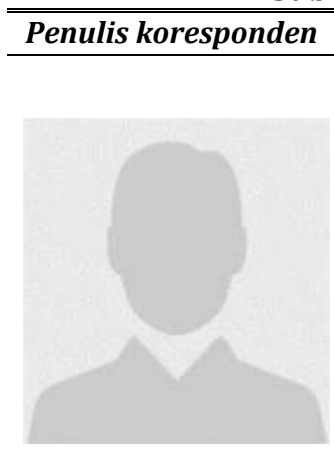

Jurnal DIALOGIKA

Manajemen dan

Administrasi

diterbitkan oleh

Program Studi

Administrasi Publik

Pascarjana Universitas

Majalengka

\begin{abstract}
This research is motivated by the low job satisfaction of employees which has an impact on service quality, aims to read and analyze: 1) organizational climate, career development, job satisfaction, and service quality in Cigasong District; 2) The magnitude of the influence of organizational climate on job satisfaction; 3) The magnitude of the influence of career development on job satisfaction; 4) The magnitude of the influence of organizational climate and career development on job satisfaction; and 5) The amount of influence of work on service quality. The research method used with survey techniques. Data collection using a questionnaire with a sample of 50 people who were determined by random sampling techniques. Data processing uses path analysis with the help of a SPSS computer program. The results of descriptive research are conducive organizational climate, transparent career development, satisfied employees, and good enough service quality; In terms of organizational climate and career development affect job satisfaction both partially and collectively, and job satisfaction affects the quality of service. Conclusion, both partially and jointly organizational climate and career development have an effect on job satisfaction and job satisfaction has an impact on service quality.
\end{abstract}

Keywords: Organizational Climate, Career Development, Job Satisfaction, And Service Quality.

\begin{abstract}
Abstrak
Penelitian ini dilatarbelakangi rendahnya kepuasan kerja pegawai yang berdampak pada kualitas pelayanan, bertujuan untuk mengetahui dan menganalisis : 1) iklim organisasi, pengembangan karir, kepuasan kerja, dan kualitas pelayanan di Kecamatan Cigasong; 2) Besarnya pengaruh iklim organisasi terhadap kepuasan kerja; 3) Besarnya pengaruh pengembangan karir terhadap kepuasan kerja; 4) Besarnya pengaruh iklim organisasi dan pengembangan karir terhadap kepuasan kerja; dan 5) Besarnya pengaruh kepuasan kerja terhadap kualitas pelayanan. Metode penelitian yang digunakan kuantitatif dengan teknik survei. Pengumpulan data menggunakan kuesioner dengan sampel sebanyak 50 orang yang ditentukan dengan teknik random sampling. Pengolahan data menggunakan analisis jalur dengan bantuan komputer program SPSS. Hasil penelitian secara deskriptif iklim organisasi kondusif, pengembangan karir transparan, pegawai cukup puas, dan kualitas pelayanan cukup baik; Secara perivikatif iklim organisasi dan pengembangan karir berpengaruh terhadap kepuasan kerja baik secara parsial maupun bersama, serta kepuasan kerja berpengaruh terhadap kualitas pelayanan. Kesimpulan, baik secara parsial maupun bersama iklim organisasi dan pengembangan karir berpengaruh terhadap kepuasan kerja dan kepuasan kerja berdampak pada kualitas pelayanan.
\end{abstract}

Kata Kunci: Iklim organisasi, pengembangan karir, kepuasan kerja, dan kualitas pelayanan. 


\section{PENDAHULUAN}

Pemerintah di tingkat kecamatan merupakan institusi pemerintah yang memiliki kewajiban untuk memberikan pelayanan kepada masyarakat sesuai dengan tujuan awalnya. Dinyatakan juga bahwa pemerintah adalah sebuah sistem multi proses yang bertujuan memenuhi dan melindungi kebutuhan dan tuntutan yang diperintah akan barang, jasa pasar, jasa publik dan layanan sipil (Ndraha,2006).

Pelayanan publik didefinisikan sebagai segala bentuk jasa pelayanan, baik dalam bentuk barang publik maupun jasa publik yang pada prinsipnya menjadi tanggung jawab dan dilaksanakan oleh instansi pemerintah, baik di pusat, daerah, maupun lingkungan BUMN/BUMD dalam rangka upaya pemenuhan kebutuhan masyarakat maupun dalam rangka pelaksanaan ketentuan perundang-undangan. Berkenaan dengan pelayanan publik, dalam implementasinya tidak terlepas dari tantangan yang akan dihadapi. Tantangan tersebut bukan sekedar suatu pelayanan yang efisien, tetapi juga bagaimana pelayanan yang diberikan dapat dilakukan tanpa membeda-bedakan status dari masyarakat yang dilayani, atau dengan kata lain bagaimana menciptakan pelayanan yang adil dan demokratis (Juantara, 2005).

Terbitnya undang-undang Nomor 25 Tahun 2009 tentang Pelayanan Publik, salah satu tujuannya untuk memberikan arah yang jelas kepada para pelaksana yang berkaitan dengan pelayanan publik agar fungsi-fungsi pemerintah berjalan secara efektif. Dengan adanya undang-undang yang berasaskan pada kepentingan umum menjamin adanya adanya kepastian hukum, kesamaan hak, keseimbangan hak dan kewajiban, keprofesionalan, partisipatif, persamaan dalam perlakuan (tidak diskriminatif), keterbukaan, akuntabilitas, fasilitas dan perlakuan khusus bagi kelompok rentan, ketepatan waktu dan kecepatan, kemudahan dan keterjangkauan serta bertujuan agar terdapat batasan hubungan yang jelas tentang hak, tanggung jawab, kewajiban, dan kewenangan seluruh pihak yang terkait dengan penyelenggaraan pelayanan publik.

Fenomena yang terjadi di lapangan, pelayanan publik di Kecamatan Cigasong belum memenuhi apa yang diharapkan, dalam arti masih terdapat beberapa kelemahan, apa yang diamanatkan dalam undang-undang belum terlaksana dengan baik. Dari hasil pengamatan peneliti, ditemukan beberapa faktor yang diduga mempengaruhi rendahnya kualitas pelayanan. Antara lain iklim organisasi, pengembangan karir pegawai, kepuasan kerja pegawai.

Iklim tidak dapat disentuh, tetapi dapat dirasakan secara psikologis berkaitan dengan persepsi pegawai terhadap suasana lingkungan pekerjaan. Antara iklim organisasi dengan kepuasan kerja saling menentukan, artinya kepuasan kerja akan tercipta apabila didukung oleh iklim organisasi yang kondusif. Iklim sangat berpengaruh terhadap kepuasan kerja pegawai dalam setiap organisasi (Wibisono, 2008; Susanti, 2012; Affandi, 2002; dan Rosnaniar, dkk, 2013). Faktor lain yang diduga berpengaruh terhadap kepuasan kerja pegawai adalah faktor pengembangan karir pegawai. Keterkaitan antara pengembangan karir dengan kepuasan kerja dinyatakan oleh Septyawati (2010); Sari (2012); Ekayadi (2009); Waspodo dan Minadaniati (2012) yang telah membuktikan secara empirik bahwa pengembangan karir dapat mempengaruhi kepuasan kerja. Dengan demikian, apabila iklim organisasi dan pengembangan karir ditingkatkan bersama dampaknya akan lebih besar terhadap peningkatan kualitas pelayanan.

Kepuasan kerja merupakan hal penting bagi pegawai dan bermanfaat untuk meningkatkan kinerja organisasi karena tingkat kepuasan kerja yang tinggi akan mempengaruhi penyelesaian pekerjaan sehingga tujuan instansi dalam memberikan pelayanan kepada publik akan tercapai secara berkualitas. Dalam penelitian ini, masalah dirumuskan : 1) Seberapa besar pengaruh iklim organisasi terhadap kepuasan kerja; 2) Seberapa besar pengaruh 
pengembangan karir terhadap kepuasan kerja; 3) Seberapa besar pengaruh iklim organisasi dan pengembangan karir terhadap kepuasan kerja secara bersama; 4) Seberapa besar pengaruh kepuasan kerja terhadap kualitas pelayanan.

\section{TINJAUAN PUSTAKA}

Iklim organisasi, pengembangan karier, kepuasan kerja dan kualitas pelayanan publik merupakan unsur-unsur yang termasuk ruang lingkup praktek administrasi. Secara teoretis, menurut Pasolong (2008:3) "administrasi adalah pekerjaan terencana yang dilakukan oleh sekelompok orang dalam bekerjasama untuk mencapai tujuan atas dasar, efektif, efisien dan rasional". Teori ini menitikberatkan administrasi pada pekerjaan yang terencana oleh sekelompok orang, dengan kata lain dalam suatu organisasi. Pendapat lain dikemukakan oleh Nawawi (1994:28) yang menyatakan bahwa "Administrasi adalah rangkaian kegiatan atau proses pengendalian, cara, atau sistem kerja sama sejumlah orang, agar berlangsung efektif dan efisien dalam mewujudkan tujuan bersama". Dalam teori ini, administrasi diartikan secara luas, sehingga bukan hanya pekerjaan terencana, melainkan meliputi rangkaian kegiatan yang dilakukan sekelompok orang dalam organisasi untuk mewujudkan tujuan bersama secara efektif dan efisien.

Dalam prakteknya, administrasi digunakan di berbagai lingkungan organisasi, baik organisasi besar maupun kecil, baik di lingkungan pemerintah maupun lingkungan swasta. Dalam penelitian ini, yang dimaksud dengan administrasi khusus di lingkungan instansi pemerintah sehingga erat kaitannya dengan teori administrasi Negara (Public Administration). Menurut Pfiffner dan Presthus dalam Pasolong (2008:7) "Administrasi publik meliputi implementasi kebijakan pemerintah yang telah ditetapkan oleh badan-badan perwakilan politik, koordinasi usaha-usaha perorangan dan kelompok untuk melaksanakan kebijakan pemerintah dan suatu proses yang erat kaitannya dengan pelaksanaan kebijakan- kebijakan pemerintah, pengarahan kecakapan dan teknik-teknik yang tidak terhingga jumlahnya, memberikan arah dan maksud terhadap usaha sejumlah orang". Dari pengertian ini lahir istilah administrasi Negara dengan lingkup yang lebih spesifik, seperti yang dikemukakan Siagian (2011:7) bahwa: "Administrasi negara ialah keseluruhan kegiatan yang dilakukan oleh seluruh aparatur pemerintah dari suatu Negara dalam usaha mencapai tujuan negara". Dalam penelitian ini, lingkup administrasi yang dimaksud lebih kecil lagi, hanya di lingkungan kecamatan terkait dengan kepuasan kerja yang berdampak pada kualitas pelayanan.

Iklim organisasi merupakan salah satu faktor yang diduga berpengaruh terhadap kepuasan kerja pegawai, sehingga pimpinan berkewajiban menciptakan iklim organisasi yang kondusif di lingkungan organisasi yang dipimpinnya. Menurut Litwin dan Stringer dalam Wirawan (2007:32) "Iklim organisasi merupakan kualitas lingkungan internal organisasi yang secara relatif terus berlangsung, dialami oleh anggota organisasi, mempengaruhi perilaku mereka dan dapat dilukiskan dalam pengertian satu set karakteristik atau sifat organisasi”. Definisi iklim organisasi lainnya dikemukakan oleh Davis dan Newstorm (2001:83) yang menyatakan "Iklim organisasi merupakan sebuah konsep yang menggambarkan suasana internal lingkungan organisasi yang dirasakan oleh anggotanya selama beraktivitas dalam rangka tercapainya tujuan organisasi".

Kaitan antara iklim organisai dengan kepuasan kerja pegawai dikemukakan oleh Stringer (2002:129) yang menyatakan bahwa karakteristik atau dimensi iklim organisasi mempengaruhi motivasi anggota organisasi untuk berperilaku tertentu. Maka, secara administrative iklim organisasi dapat diukur melalui enam dimensi, yaitu struktur organisasi, standar-standar, tanggung jawab, penghargaan, dukungan, dan komitment. Teori lain yang mengungkap tentang dimensi iklim organisasi dikemukakan oleh Kelneer dalam Lila (2002:65), bahwa untuk melihat kondisi iklim organisasi di suatu instansi dapat dilihat dari dimensi "Flexibility 
conformity, Responsibility, Standards, Reward, Clarity, and Tema commitment". Dari telaah teori tersebut disimpulkan bahwa iklim organisasi adalah gambaran suasana lingkungan internal organisasi yang akan dirasakan oleh anggota, baik secara fisik maupun non fisik yang akan berpengaruh terhadap suasana kerja pegawai.

Faktor lain yang erat kaitannya
dengan kepuasan kerja adalah
pengembangan karir, bahkan terkait langsung dengan kepentingan pribadi pegawai yang sangat mendasar. Menurut Rivai (2003:290) "Pengembangan karir adalah proses peningkatan kemampuan kerja individu yang dicapai dalam rangka mencapai karir yang diinginkan". Pengertian dalam arti yang lebih luas dikemukakan Mathis dan Jackson (terjemahan) (2006:342) bahwa "Karir adalah rangkaian posisi yang berkaitan dengan kerja yang ditempati seseorang sepanjang hidupnya". Dalam pelaksanaannya, pengembangan karir tidak dapat dilakukan dalam waktu singkat, melainkan memerlukan waktu dan proses yang berkesinambungan mencakup tahapan perencanaan karir dan manajemen karir (Gomes, 2003:215). Secara umum, perlunya pengembangan karir dikemukakan Rivai (2004:291), bahwa "Pengembangan karir yang dirancang secara baik akan membantu dalam menentukan kebutuhan karir mereka sendiri dan menyesuaikan antara kebutuhan karyawan dengan tujuan perusahaan/ instansi". Bentuk pengembangan karir antara lain melalui pendidikan, promosi, dan mutasi dengan memperhatikan tiga hal, yaitu menaksir kebutuhan karir, kesempatan karir, dan menyesuaikan kebutuhan dengan kesempatan karir. (Flippo dalam Wahyudi, 2002:163). Pandangan lain dikemukakan Wahyudi (2002:163) yang menyatakan tentang faktor-faktor yang perlu dipertimbangkan dalam pengembangan karir, yaitu : a) Perlakuan yang adil dalam berkarir; b) Kepedulian atasan langsung; c) Informasi tentang berbagai peluang promosi; d) Minat untuk dipromosikan; dan e) Tingkat kepuasan. Dengan demikian, pengembangan karir adalah upaya pimpinan dalam menyeimbangkan kebutuhan organisasi dengan kapasitas pegawai, dilakukan melalui peningkatan pengetahuan dan keterampilan berasaskan keadilan. Dengan adanya pengembangan karir pegawai memiliki kesempatan untuk mempersiapkan masa depan sesuai dengan potensinya. Pengembangan karir yang terencana dengan baik, berasaskan keadilan dan ditunjang dengan adanya kepedulian pimpinan akan mendorong pegawai untuk bekerja lebih giat dan merasa puas.

Kepuasan kerja berkenaan dengan suasana hati pegawai secara personal. Menurut Kinicki et.al dalam Schultz (2006:19) "Kepuasan kerja lebih mengacu pada perasaan positif dan negatif dan sikap pekerja pada pekerjaannya". Pendapat lain dikemukakan George dan Jones (2005:20), bahwa "Kepuasan kerja dinyatakan sebagai kumpulan perasaan dan kepercayaan dan pikiran yang dimiliki seseorang tentang bagaimana mereka berprilaku dengan penuh penghargaan atas pekerjaannya". Colquitt, Lepine, dan Wesson (2009:45), mengemukakan bahwa "Kepuasan kerja adalah suatu pernyataan emosi yang menyenangkan yang dihasilkan dari penghargaan terhadap pekerjaan seseorang dan apa yang anda pikirkan tentang pekerjaan anda". Untuk mengetahui kadar kepuasan kerja pegawai, menurut Riva'i (2004:479) dapat dilihat dari beberapa faktor kepuasan kerja diantaranya adalah ; “a) Isi pekerjaan; b) Supervisi; c) Organisasi dan manajemen; d) Kesempatan untuk maju; e) Gaji dan keuntungan dalam bidang finansial; f) Rekan kerja; dan g) Kondisi pekerjaan". Dalam penelitian ini, pengukuran kepuasan kerja menggunakan pendapat Spector dalam Yuwono, (2005:69) dengan sembilan aspek yaitu : a) Upah, meliputi jumlah dan rasa keadilannya; b) Promosi, meliputi peluang dan rasa keadilan untuk mendapatkan promosi; c) Supervisi, meliputi keadilan dan kompetensi penugasan menajerial oleh penyelia; d) Benefit, meliputi asuransi, liburan dan bentuk fasilitas yang lain; e) Contingent rewards, meliputi rasa hormat, diakui dan diberikan apresiasi; f) Operating procedures, meliputi kebijakan, prosedur dan aturan; g) Coworkers, meliputi rekan 
kerja yang menyenangkan dan kompeten; $\mathrm{h}$ ) Nature of work, meliputi tugas itu sendiri dapat dinikmati atau tidak; dan i) Communication, meliputi berbagai informasi di dalam organisasi (verbal maupun nonverbal)". Dengan demikian, seorang pegawai yang merasa dihargai hasil kerjanya akan merasa puas dan berdampak pada kualitas pelayanan.

Dalam suatu instansi pemerintah, terutama di tingkat kecamatan yang banyak berinteraksi dengan anggota masyarakat kepuasan kerja pegawai erat sekali kaitannya dengan kualitas pelayanan. Menurut Triguno (1997:76) kualitas pelayanan adalah "Suatu standar yang harus dicapai oleh seseorang atau kelompok atau lembaga atau organisasi mengenai kualitas sumber daya manusia, kualitas cara kerja, proses dan hasil kerja atau produk yang berupa barang dan jasa." Dalam arti yang lebih luas, kualitas pelayanan dilihat dari berbagai segi memiliki banyak definisi seperti yang dikemukakan Tjiptono (1997:2), yaitu : a) Kesesuaian dengan persyaratan atau tuntutan; b) Kecocokan untuk pemakaian; c) Perbaikan atau penyempurnaan berkelanjutan; d) Bebas dari kerusakan atau cacat; e) Pemenuhan kebutuhan pelanggan semenjak awal dan setiap saat; f) Melakukan segala sesuatu secara benar semenjak awal; dan g) Sesuatu yang bisa membahagiakan pelanggan". Untuk mengetahui kadar kualitas pelayanan ini, peneliti menggunakan teori yang dikemukakan Tjiptono dan Anastasia (2003:27), dengan lima karakteristik yang digunakan oleh pelanggan dalam mengevaluasi kualitas pelayanan, yaitu: a) Bukti langsung (tangibles), meliputi fasilitas fisik, perlengkapan, pegawai, dan sarana komunikasi; b) Kehandalan (reliability), yakni kemampuan dalam memberikan pelayanan yang dijanjikan dengan segera dan memuaskan; c) Memiliki daya tanggap (responsiveness), yaitu keinginan para staf untuk membantu para pelanggan dan memberikan pelayanan dengan tanggap; d) Adanya jaminan (assurance), mencakup kemampuan, kesopanan, dan sifat dapat dipercaya yang dimiliki para staf, bebas dari bahaya risiko atau keragu-raguan; e) Empati, meliputi kemudahan dalam melakukan hubungan komunikasi yang baik, dan memahami kebutuhan para pelanggan". Dengan memperhatikan teori tersebut, pelayanan dikatakan berkualitas apabila pengguna jasa atau pelanggan merasa kebutuhannya terpenuhi dengan nyata, cepat, tepat, mudah, menyenangkan dan dapat dipercaya,

Berdasarkan telaah teori tentang variabel iklim organisasi, pengembangan karir, kepuasan kerja, dan kualitas pelayanan peneliti berasumsi bahwa keempat variabel tersebut memiliki keterkaitan satu sama lain. Iklim organisasi yang kondusif dan pengembangan karir yang jelas dapat mempengaruhi kepuasan kerja pegawai serta berdampak pada peningkatan kualitas pelayanan. Keterkaitan antar variabel tersebut, diilustrasikan dalam gambar di bawah ini.

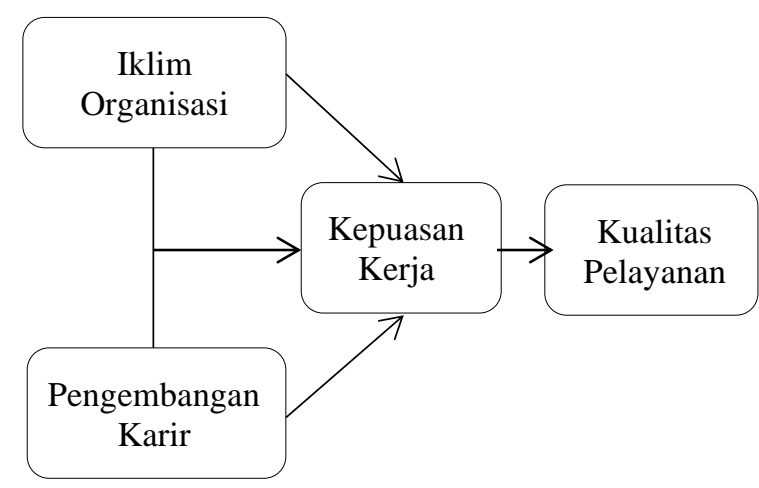

Gambar : 1. Kerangka Konsep

Dengan memperhatikan kerangka konsep didasarkan atas telaah teori, hipotesis penelitian yang diajukan adalah:

1. Terdapat pengaruh iklim organisasi terhadap kepuasan kerja

2. Terdapat pengaruh pengembangan karir terhadap kepuasan kerja

3. Terdapat pengaruh iklim organisasi dan pengembangan karir secara bersama terhadap kepuasan kerja.

4. Terdapat pengaruh kepuasan kerja terhadap kualitas pelayanan.

\section{METODE PENELITIAN}

Penelitian ini adalah penelitian survey, yaitu penelitian dengan menggunakan sampel dari sekelompok populasi serta menggunakan kuesioner 
sebagai pengumpul data utama. Dalam penelitian ini unit analisisnya berupa individu (Singarimbun, 2006), oleh karena itu unit analisisnya berupa individuindividu di lingkungan Kantor Kecamatan Cigasong ditambah dengan anggota masyarakat yang dilayani. Penelitian survey ini menggunakan penelitian penjelasan, yakni penjelasan tentang hubungan kausalitas antarvariabel penelitian melalui pengujian hipotesis.

Sumber data yang digunakan dalam penelitian ini adalah data primer dan sekunder. Data primer adalah data yang diperoleh langsung dari responden tentang aspek iklim organisasi, pengembangan karir, kepuasan kerja, dan kualitas pelayanan yang dikumpulkan melalui teknik kuesioner. Sedangkan data sekunder adalah data-data yang diperoleh melalui dokumen dan sumber lain. Sampel dalam penelitian ini ditetapkan sebanyak 100, terdiri atas aparat kantor Kecamatan dan anggota masyarakat dengan teknik proportionate random sampling. Data yang diperoleh dianalisis dengan dua cara, yakni : a) Metode statistik deskriptif untuk menggambarkan kondisi iklim organisasi, pengembangan karir, kepuasan kerja, dan kualitas pelayanan secara deskriptif dalam bentuk frekuensi; dan b) Metode statistik inferensial dengan tujuan untuk menguji pengaruh variabel bebas terhadap variabel terikat secara perivikatif menggunakan analisis jalur dengan struktur analisis sebagai berikut:

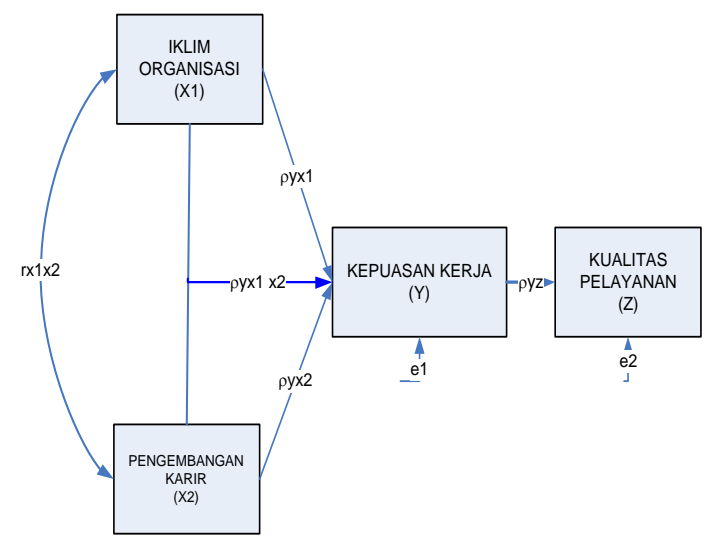

Gambar 2. Struktur Analisis Jalur
Sesuai dengan rumusan masalah dan tujuan penelitian serta rancangan analisis data, hasil penelitian disajikan dalam dua jenis, yaitu hasil analisis deskriptif dan analisis perivikatif sebagai berikut:

1. Hasil Analisis Deskriptif

Dari hasil analisis terhadap variable iklim organisasi, pengembangan karir, kepuasan kerja, dan kualitas pelayanan didasarkan atas jawaban responden terhadap kuesioner yang disebarkan diperoleh hasil secara umum bahwa menurut persepsi responden, iklim organisasi cukup kondusif, pengembangan karir transfaran dan berkeadilan, kepuasan kerja cukup puas, dan kulitas pelayanan cukup baik. Namun untuk masing-masing variabel terdapat kelemahan pada aspek tertentu yang merupakan temuan empiris dalam penelitian imi.

\section{Hasil Analisis Perivikatif}

Hasil analisis perivikatif didasarkan atas hasil pengolahan dan analisis data dengan metode statistik inferensial menggunakan analisis jalur, proses penghitungan menggunakan bantuan komputer program SPSS for Window versi 20.0 setelah dilakukan diperoleh hasil sebagai berikut:

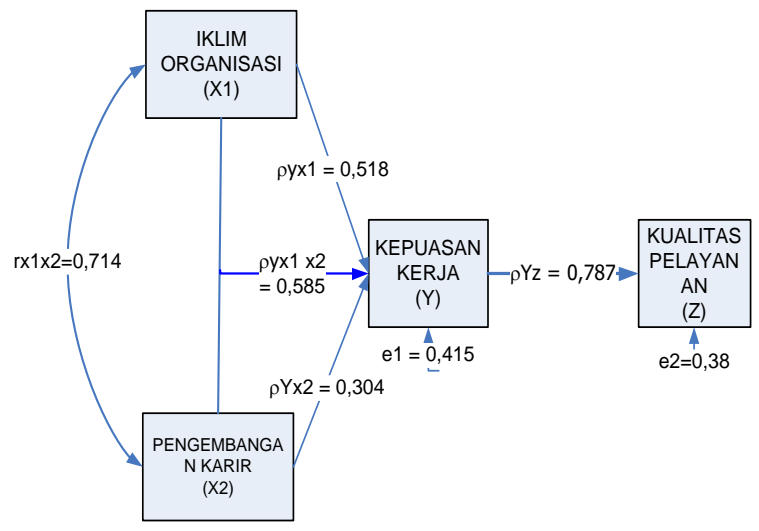

Gambar: 3. Hasil Analisis Jalur

Dari hasil analisis jalur sebagaimana tertera pada Gambar 3 di atas, dapat dijelaskan sebagai berikut:

a. Hubungan iklim organisasi dengan pengembangan karir

Nilai koeffisien korelasi antara iklim organisasi dengan pengembangan karir sebesar 0,714. Setelah diinterpretasikan masuk kategori hubungan yang cukup 
kuat dan searah. Artinya antara iklim organisasi dan pengembangan karir memiliki hubungan yang cukup kuat yang sehingga masing-masing dapat saling melengkapi.

b. Pengaruh iklim organisasi terhadap kepuasan kerja secara parsial

Pengaruh langsung iklim organisasi terhadap kepuasan kerja pegawai memiliki nilai koefisien jalur sebesar 0,518; sehingga kontribusi pengaruhnya secara langsung sebesar 26,83\%. Pengaruh tidak langsung dari iklim organisasi terhadap kepuasan kerja melalui pengembangan karir sebesar $11,24 \%$, dengan total pengaruh sebesar $38,07 \%$. Kemudian, dari hasil pengujian hipotesis diperoleh nilai t-hitung sebesar 3,857 dengan nilai t-tabel sebesar 2,00. Dengan demikian, karena thitung $(3,857)>$ t-tabel $(2,00)$ maka dapat diartikan bahwa iklim organisasi berpengaruh terhadap kepuasan kerja secara signifikan dan hipotesis dapat diterima.

c. Pengaruh pengembangan karir terhadap kepuasan kerja secara parsial

Pengaruh langsung pengembangan karir terhadap kepuasan kerja pegawai memiliki nilai koefisien jalur sebesar 0,304; sehingga kontribusi pengaruhnya secara langsung sebesar 9,24\%. Pengaruh tidak langsung dari pengembangan karir terhadap kepuasan kerja melalui iklim organisasi sebesar $11,24 \%$, dengan total pengaruh sebesar $20,48 \%$.

Dari hasil pengujian hipotesis secara parsial dari pengembangan karir terhadap kepuasan kerja diperoleh nilai t-hitung sebesar 2,264 dan nilai t-tabel sebesar 2,00. Dengan demikian, karena t-hitung $(2,264)>$ t-tabel $(2,00)$ maka dapat diartikan bahwa pengembangan karir berpengaruh terhadap kepuasan kerja secara signifikan dan hipotesis dapat diterima.

d. Pengaruh iklim organisasi dan pengembangan karir terhadap kepuasan kerja secara bersama.
Dari hasil analisis jalur diperoleh data bahwa nilai koefisien jalur antara iklim organisasi dan pengembangan karir sebesar 0,585 dengan koeffisien determinasi sebesar 0,3422 atau 34,22\%. Artinya keragaman kepuasan kerja dipengaruhi oleh iklim organisasi dan pengembangan karir sebesar 34,22\% dan sisanya sebesar $65,78 \%$ dipengaruh oleh faktor lain di luar model penelitian. Pengujian hipotesis secara simultan dari iklim organisasi dan pengembangan karir terhadap kepuasan kerja memiliki nilai Fhitung sebesar 33,171 dan F-tabel sebesar 8,57. Oleh karena F-hitung $(33,171)>$ F-tabel $(8,57)$ maka dapat disimpulkan bahwa iklim organisasi dan pengembangan karir secara bersama berpengaruh secara signifikan terhadap kepuasan kerja. Dengan demikian hipotesis terbukti atau dapat diterima, bahwa baik secara bersama maupun parsial iklim organisasi dan pengembangan karir berpengaruh terhacdap kepuasan kerja pegawai.

e. Pengaruh kepuasan kerja terhadap kualitas pelayanan

Dari hasil analisis jalur diperoleh nilai koeffisien korelasi dari kepuasan kerja terhadap kualitas pelayanan sebesar 0,787 dengan nilai koefisien determinasi sebesar 0,620 atau 62,00\%. Artinya keragaman kualitas pelayanan dipengaruhi oleh kepuasan kerja sebesar $62,00 \%$ dan sisanya sebesar $48,00 \%$ dipengaruh oleh faktor lain di luar model penelitian. Pengujian hipotesis secara parsial dari kepuasan kerja terhadap kualitas pelayanan diperoleh nilai t-hitung sebesar 8,852 dan nilai $\mathrm{t}$ table sebesar 2,00. Oleh karena nilai t-hitung $(8,852)>$ t-tabel $(2,00)$, maka dapat disimpulkan bahwa kepuasan kerja berpengaruh secara signifikan terhadap kualitas pelayanan yang berarti hipotesis dapat diterima.

Dari hasil penelitian di atas secara logika dapat dipahami bahwa baik iklim organisasi maupun pengembangan karir yang menunjukkan pengaruhnya terhadap kepuasan kerja pegawai, karena kedua 
variabel tersebut merupakan faktor penentu bagi pembentuk kepuasan kerja secara individual. Iklim organisasi merupakan faktor eksternal yang sangat erat kaitannya dengan proses pelaksanaan kerja. Jadi, apabila iklim organisasi tidak kondusif, apalagi menjadikan hambatan jelas akan mengurangi kinerja pegawai karena pegawai akan merasa tidak nyaman, bahkan merasa tidak aman. Sedangkan pengembangan karir erat kaitannya dengan nasib individu pegawai yang berdampak pada motivasi kerja dan harapan pegawai. Pengembangan karir yang tidak transfaran dan tidak memiliki azas keadilan, akan menimbulkan ketidakpuasan, bahkan kekecewaan yang berdampak pada penurunan kinerja. Oleh karena itu, logis jika pengembangan karir berpengaruh terhadap kepuasan kerja pegawai.

Apabila kedua variabel tersebut secara individu berpengaruh terhadap kepuasan kerja pegawai, apalagi jika digabungkan atau berperan bersama-sama, tentu pengaruhnya akan semakin kuat. Hal ini berimplikasi bahwa manajer puncak, dituntut untuk mampu menciptakan kondisi yang saling mendukung antara penciptaan iklim organisasi yang kondusif dengan proses pengembangan karir yang transfaran dan berkeadilan.

Dampak dari kepuasan kerja pegawai akan dirasakan oleh semua warga organisasi dalam bentuk kinerja organisasi yang tinggi dan tercapainya tujuan yang telah direncanakan. Bagi organisasi pemerintah yang lebih banyak berfokus kepada pelayanan publik, kepuasan kerja pegawai akan sangat mendukung untuk memberikan pelayanan yang lebih berkualitas.

\section{SIMPULAN}

Hasil penelitian dan analisis data menunjukkan bahwa persepsi responden tentang iklim organisasi dikategorikan baik. Hasil ini akan memberikan petunjuk bagi manajer untuk dapat meningkatkan dan mempertahankan iklim organisasi yang telah kondusif. Hal ini dikarenakan iklim organisasi erat kaitannya dengan suasana hati para pegawai, sehingga harus dijaga agar tetap kondusif agar pegawai merasa betah, aman, nyaman dan bersemangat untuk melaksanakan tugas dan tanggungjawabnya.

Untuk variabel pengembangan karir, hasil penelitian menunjukan bahwa persepsi responden terhadap pola pengembangan karir dikategorikan baik. Hal ini memberikan petunjuk bagi manajer agar dapat mempertahankan yang sudah baik dan memperbaiki yang masih lemah. Pengembangan karir pegawai yang transfaran dan berkeadilan akan memberikan dampak positif terhadap pegawai, antara lain merasa dihargai, harapannya terpenuhi dan mengurangi kecemburuan antarpegawai. Selain itu, pengembangan karir yang berkeadilan akan menumbuhkan rasa hormat terhadap atasan dan siap melaksanakan tugas atas kesadaran sendiri.

Untuk variable kepuasan kerja, hasil penelitian menunjukan bahwa kepuasan kerja pegawai dikategorikan tinggi. Hasil ini dapat dijadikan bahan pertimbangan bagi manajer guna meningkatkan kinerja organisasi dalam upaya meningkatkan kulitas pelayanan kepada publik. Kepuasan kerja pegawai yang sudah baik dipertahankan dan yang masih lemah diperbaiki, barengi dengan sikap ramah dan transfaran yang memungkinkan iklim organisasi juga semakin kondusif karena saling mempengaruhi.

Untuk variabel kualitas pelayanan, hasil penelitian menunjukkan bahwa kualitas pelayanan dikategorikan baik. Hasil ini dapat dijadikan bahan pertimbangan bagi manajer untuk terus berusaha meningkatkan kualitas pelayanan dengan cara mempertahankan yang sudah baik dan memperbaiki yang masih lemah.

Dari hasil analisis verivikatif dengan pendekatan statistik menunjukkan bahwa iklim organisasi berpengaruh terhadap kepuasan kerja pegawai, dengan besaran pengaruh 38,07\%; Pengembangan karir berpengaruh terhadap kepuasan kerja pegawai, dengan besaran pengaruh $00 \%$. Iklim organisasi dan pengembangan karir secara bersama berpengaruh terhadap 
kepuasan kerja pegawai, dengan besaran pengaruh 20,48\%. Hal ini menunjukkan bahwa berdasarkan persepsi responden tentang iklim organisasi dan pengembangan karir secara bersama berpengaruh terhadap kepuasan kerja pegawai, dengan besaran pengaruh $34,22 \%$. Kemudian, secara parsial hasil penelitian menunjukkan bahwa kepuasan kerja pegawai berpengaruh terhadap kualitas pelayanan kepada publik, dengan besaran pengaruh $62,00 \%$, sisanya sebesar $48,00 \%$ dipengaruh oleh faktor lain di luar model penelitian.

Dengan demikian, secara keseluruhan dapat disimpulkan bahwa iklim organisasi dan pengembangan karir baik secara parsial maupun bersama berpengaruh terhadap kepuasan kerja pegawai. Kepuasan kerja pegawai berpengaruh terhadap kualitas pelayanan.

\section{DAFTAR PUSTAKA}

Al Rasyid, Harun. (1997). Kajian Awal Birokrasi Pemerintahan dan Politik. Yogyakarta : Pustaka Pelajar.

Allison, M., dan Kaye, J. (2005). Perencanaan Strategis Bagi Organisasi. Jakarta : Rineka Cipta.

Alma, B. (2005). Kewirausahaan Untuk Mahasiswa dan Umum. Bandung : Alfabeta.

Arikunto dan Sopiah. (2008). Budaya Organisasi, Komitmen Organisasional Pimpinan dan Pengaruhnya. Bandung : PT. Remaja Rosdakarya.

Arikunto, Suharsimi. (2002). Prosedur Penelitian. Jakarta : PT. Gramedia Pustaka Utama.

Arnold, John. (2005). Work Psychology : Understanding Human Behaviour in the Workplace. Jakarta : PT. Gramedia Pustaka Utama.

Bambang Wahyudi. (2002). Manajemen Sumber Daya Manusia. Bandung : Sulita.

Badan Standar Nasional Pendidikan. (2006). Panduan Penyusunan Kurikulum Tingkat Satuan Pendidikan Jenjang Pendidikan Dasar dan Menengah. Jakarta: BSNP.
Boediono, B. (2003). Reformasi Pelayanan Publik. Jakarta : Rineka Cipta.

Davis, Keith dan Newstrom. (2000). Perilaku Dalam Organisasi. Jakarta : Erlangga.

Davis, Keith. (2001). Perilaku Organisasi. Jakarta : PT. Gramedia Pustaka Utama.

Deli dan Ali M.B. (2010), Dasar-dasar Perbankan. Jakarta : PT. Raja Grafindo Persada.

Fathoni, Abdurrahmat. (2006). Manajemen Sumber Daya Manusia. Jakarta : Rineka Cipta.

Garry, Y (2002). Manajemen Personalia Prenhalindo. Jakarta : Binaman Presindo.

Gelora Aksara Pratama. Jackson, John H. Dan Robert L. Mathis. (2006). Manajemen Sumber Daya Manusia. Terjemahan Diana Angelia. Yogyakarta : Pustaka Pelajar.

George, J. M., G. R. Jones. (2002). Marketing Professional Services Understanding and Managing Organizational Behaviour. Jakarta : PT. Gramedia Pustaka Utama.

Gerson F. Richard. (2000). Mengukur Kepuasan Pelanggan. Yogyakarta : Andi.

Ghozali, Imam. (2005). Aplikasi Analisis Multivariate dengan Program SPSS. Semarang : Badan Penerbit Universitas Diponegoro.

Hariandja, Marihot Tua Efendi. (2002). Manajemen Sumber Daya Manusia. Jakarta : Grasindo.

Hughes, Ginnet, Curphy. (2009). Leadership : Enhancing the Lessons of Experience. New York : The Free Press.

Husein Umar. (2007). Metode Riset Bisnis. Jakarta : PT. Gramedia Pustaka Utama.

J. Dubrin, Andrew. (1982). Personal and Human Resources Management. Jakarta : PT. Gramedia Pustaka Utama.

Jennifer M. George dan Gareth R. Jones. (2005). Understanding and Managing. Riset Sumber Daya Manusia. Jakarta : PT. Gramedia Pustaka Utama. 
Kopelman, R. E. (1986). Managerial Economics. Jakarta : PT. Gramedia Pustaka Utama.

Lila, J. T. (2002). Managerial Economis. USA : South Western College. Hill.

Lukman, Sampara. (2000). Manajemen Kualitas Pelayanan. Jakarta : Pustaka Sinar Harapan. Grafindo Persada.

Mangkunegara, A. A. Anwar Prabu. (2000). Manajemen Sumber Daya Manusia. Bandung : PT. Remaja Rosdakarya.

(2000). Manajemen Sumber Daya Manusia. Bandung : PT. Remaja Rosdakarya.
Ndraha, Taliziduhu. (1999). Pengantar Teori Pengembangan Sumberdaya Manusia. Jakarta : Rineka Cipta. . (2006). Budaya Organisasi. Jakarta : Rineka Cipta.

(2006). Pembangunan Masyarakat. Jakarta : Rineka Cipta.

Rivai, Veithzal. (2003). Kepemimpinan dan Perilaku Organisasi. Jakarta : Raja Grapindo Persada

\section{BIOGRAFI PENULIS}

\begin{tabular}{||l|l||}
\hline & $\begin{array}{l}\text { Endang Hermawan, Alumni Program Studi Magister Ilmu Administrasi, } \\
\text { Pascasarjana Universitas Majalengka, ProVinsi Jawa Barat, Indonesia. } \\
\end{array}$ \\
e-mail : endanghermawan@gmail.com & \\
\hline
\end{tabular}

